\title{
Organizational culture mapping analysis through Organizational Culture Assessment (OCA)
}

\author{
Analisis pemetaan budaya organisasi menggunakan Organizational \\ Culture Assessment (OCA)
}

\author{
Kartika Mega Tama \\ Department of Health Administration and Policy, Faculty of Public Health, Universitas Airlangga \\ Address: Kampus C, Mulyorejo, Surabaya, East Java 60115 \\ E-mail: kartika.mega.tama-2015@fkm.unair.ac.id
}

\begin{abstract}
Organization is characterized by the different senses of culture and uniqueness that distinguish one's entity from others. Culture plays an important role in organization as a good culture can provide organization support to achieve goals. Organizational culture acts as a guideline for an individual's daily behavior that will influence the decision-making process and provide direction for leaders and members to achieve organizational goals. In its creation, organizational culture was built according to organization circumstances. Organizational culture has important roles in the maintenance and development of the organization's vision and mission. Organizational culture is an essential tool in the improvement of organizational performance and member capability. Therefore, there is an need for the Karawitan Dance Activity Unit (UKTK) of Universitas Airlangga to project the state of the existing and expected culture of the organization. By conducting cultural mapping, existing visions and missions of an organization can be transformed. Organizational culture was measured by the Organizational Culture Assessment (OCA) method. The measurement is held by distributing instruments and contains 20 questions. The questionnaire was distributed to both leaders and members of the UKTK Airlangga University and its aim was to identify the expected culture of the university relative to the reality of culture. The results of the questionnaire showed that respondents felt the culture at the UKTK is of a mechanistic nature. Similarly, the expected culture of the UKTK is of a mechanistic nature. The compatibility between cultural reality and expectations in the UKTK supports organizational goals. This situation can generate good relationships between the leaders and members of the UKTK Airlangga University which results in harmony throughout the organization. The existing mechanistic organizational culture can be seen as a strategy by which to achieve the objectives of the UKTK in Airlangga University. The results of the study can also strengthen the organizational culture as it can be a powerful means by which to control and increase the consistent behavior of members of the organization. In addition, the awareness of the existing organizational culture can facilitate the implementation of work programs agreed upon by the UKTK organization of Airlangga University.
\end{abstract}

Keywords: organizational culture; OCA (Organizational Culture Assessment); mechanistic culture

Abstrak
Setiap organisasi mempunyai budaya masing-masing yang menjadi ciri khas organisasi tersebut. Budaya
memegang peranan yang penting dalam organisasi karena budaya yang baik dapat memberikan kenyamanan
yang kemudian menunjang tercapainya tujuan organisasi. Budaya organisasi adalah suatu pedoman tingkah
laku sehari-hari yang dapat mempengaruhi dalam pembuatan keputusan dan dapat mengarahkan tindakan
pemimpin dan anggota untuk mencapai tujuan organisasi. Budaya organisasi tidak muncul begitu saja,
namun harus diciptakan sesuai kondisi organisasi. Budaya organisasi memiliki peran dan elemen penting
dalam mempertahankan serta mengembangkan visi dan misi organisasi. Budaya organisasi merupakan alat
yang sangat strategis untuk meningkatkan kinerja organisasi dan kinerja para anggota yang ada dalam
organisasi. Oleh karena itu, Unit Kegiatan Tari Karawitan (UKTK) Universitas Airlangga juga perlu
melakukan pemetaan budaya yang dihadapi saat ini dengan budaya yang diharapkan. Dengan melakukan
pemetaan budaya, organisasi dapat menghadapi perubahan visi maupun misi yang sudah ada. Untuk
mengetahui budaya organisasi dapat melakukan pengukuran budaya organisasi dengan menggunakan
metode OCA (Organizational Culture Assessment). Pengukuran tersebut dilakukan dengan menyebarkan
instrumen yang berisi 20 pertanyaan. Kuesioner tersebut disebarkan kepada responden yang terdiri atas
pimpinan dan anggota UKTK Universitas Airlangga. Pengukuran ini dilakukan untuk melihat budaya 
yang diharapkan dan kenyataan budaya saat ini yang ada di organisasi sudah sesuai atau belum. Hasil pengukuran budaya yang dirasakan dalam UKTK Universitas Airlangga adalah budaya mekanistik. Begitu pula dengan budaya yang diharapkan ada dalam UKTK Universitas Airlangga adalah budaya mekanistik. Adanya kesesuaian antara kenyataan dan harapan budaya organisasi dalam UKTK Universitas Airlangga dapat mendukung tujuan organisasi. Hal tersebut dapat menciptakan hubungan baik antara pimpinan dengan anggota UKTK Universitas Airlangga dan menimbulkan kondisi yang harmonis dalam organisasi. Budaya organisasi mekanistik yang ada dapat menjadi strategi untuk mencapai tujuan UKTK Universitas Airlangga. Oleh karena itu hasil penelitian dapat memperkuat budaya organisasi yan $g$ terbentuk di UKTK Universitas Airlangga karena dapat sebagai sarana yang kuat untuk mengontrol dan meningkatkan perilaku konsisten anggota organisasi. Selain itu dengan mengetahui budaya organisasi yang ada dapat mempermudah pelaksanaan program kerja yang telah disepakati organisasi UKTK Universitas Airlangga.

Kata kunci: budaya organisasi; OCA (Organizational Culture Assessment); budaya mekanistik

\section{Introduction}

The terms of 'organization' originated from Latin organum referred as tool or body. Organizations are defined as human collectivities whose activities are coordinated and controlled to achieve a set goal (Mills \& Mills 2000). Organization is also a group of people arranged in a team that work together to achieve common goals. It could also be interpreted as a group of two or more people who have a governance structure and division of labor that works together to achieve a common goal (Astuti 2013). Organization is a collaboration of two or more people work together for common interests. Organizations can be divided into two types, namely formal organizations and informal organizations. Formal organizations defined as goal-oriented entity designed to accommodate efforts of organization members. On the other hand, informal organizations occurred spontaneous and flexible, also independently organized (Winardi 2003).

Organizational culture is one of the most influential factor in organization. Organizational culture or "Corporate Culture" interpreted as a set of values and norms that has been accepted and complied on by members. Culture creates a sense belonging for organization members. Organizational culture also applicable as a framework which set guidelines for member behavior, thus lead to a particular decision for members and directs their actions to achieve organizational goals (Zainal et al. 2014). Organizational culture also defined as a shared system adopted by members that is helpful to distinguish and add sense of uniqueness of one organization compare to other organization (Robbins \& Judge 2008).

Organizational culture reflects values upheld by the members, dominant leadership style, language and symbols, procedures and routines, and definitions of achievements that add a sense of uniqueness of an organization (Michelle 2006). In addition, achieving success in organization cannot be separated from human resource management. Human resource management was deemed as immensely important to determine organization achievement. The value was not instantly built, rather continuously constructed according to the circumstances of the organization. Culture that was implemeted, maintained and strengthened in accordance with internal and external environment of the organization will lead to the success of the organization. Organizational culture is not only seen as a legacy of the past, but can also be utilized as a tool to achieve organizational interest. It plays an important role to exercise organizational competitiveness (Iriani 2010).

One cannot describe culture without using tools or mechanism to observe it. Culture plays an important role in providing supports toward the improvement of member performance. It attracts member by adding uniqueness that became the characteristic of an organization. Strong culture growth and development will become the main motivation for an organization to improve them. Organizational culture can influence the level of satisfaction of members, thus they become more loyal in performing their activities. If values and norms adopted by the organization is in accordance with members' expectation, organization will create a sense of comfort. The confort will create interaction between members in providing their best abilities within the organization. Member consistency is a tremendeous asset for the organization. However, a developing culture can also sometimes be a 
burden when value that has been adopted by the organization was no longer suitable with organization goals. Culture that has been internalized in an organization can no longer fit organization vision if the organization go through development that alter their vision and mission. A stagnant culture in organizaion will become the reason for organizational performance decline.

There are various types of organizations ranging on different scope and size. Each organization pratices their culture differently. The life and continuity of an organization is visible because of their culture. In this context, culture does not refer to the diversity of race, ethnicity, and individual background, rather as an organization way of life. Organizational culture includes an emotional and psychological sense such as employee morale, attitude, and level of productivity. Organizational culture also can be observed through symbols such as actions, routines, and conversations, and value that attached people to these symbols. A community can comprehend culture through interactions between employees and management. However, in terms of creating and growing an organizational culture cannot be merely described based on members' sense of comfort. There are many other factors that should be taken into account such as careful thinking and how it influences the culture development that will create a good impact on an organization.

Organizational culture measurement is executed through various methods. This research applies Reigle (2003) method entitled Organizational Culture Assessment: Development of a Descriptive Test Instrument in order to analyze the suitability of expectations and reality of organizational culture. Reigle designed an instrument for organizational culture research known as Organizational Culture Assessment (OCA). OCA method was equipped with five dimensions for measuring organizational culture namely language, artifacts and symbols, behavior patterns, values, and basic assumptions. Researchers choose this method because of the measurement instrument complexity that cannot be finding in other methods (Reigle 2003).

Other studies that apply OCA method in conducting cultural assessments in an organization can be fiound in the work of Rachmawati about the Identification and Analysis of Corporate Culture at the SCC \& C (Spread Cooking Category and Culinary) Plant of PT Unilever Indonesia TBK., Cikarang. The study aims to identify corporate culture to find the dominant type of culture and the type of expected culture in the future. By conducting cultural mapping, researchers are able to map perception differences of the current corporate culture and the expected culture between leaders and members. Iriani (2010) also observe through five dimensions to determine organizational culture. The five dimensions used in the research are language, artifacts and symbols, behavior patterns, values, and basic assumptions. The language dimension used in the company reflects the feeling of respect for everyone in every levels of position in the company. The dimensions of artifacts and symbols are used to reflect the existence of unity and support in the organization. The dimensions of behavior patterns rdescribed the responsibilities of members in completing organizational tasks. The dimensions of values need to be measured to find out the cooperation and innovation of members in an organization. While the dimensions of basic assumptions are measured to assess the importance of member as assets for companies or organizations. The study uses samples in formal organizations, namely the Unilever Company. The results of the cultural assessment by using the OCA instrument show that the organizational culture in the company at the time of research and the expected culture has the same type of culture namely organic culture (Iriani 2010).

The OCA method has two types of organizational culture that become the base of instruments, namely mechanistic culture and organic culture. According to Burns \& Stalker (1961) organizations are distingusihes into two types, mechanistic and organic organizations. The mechanistic type of culture in the organization has a structured job description. In mechanistic culture, interactions between superiors and subordinates are vertical, closed, and have limitations. Member behavior in a mechanistic organizational culture is governed by the instructions of the organization's leader. Therefore, members' work motivation influenced by the fear of sanction. Mechanistic organizations are very suitable for organizational situations with high stability. The information process that exists in organizations with a mechanistic culture is carried out routinely ie repeatedly, changes slowly, and is easily understood (Knight \& McDaniel 1979). 
The second type of OCA measurement for known as organic culture. In organic culture, communication within an organization is open and free. Organizations with organic culture involved all levels in their decisions making process. Decision making was not solely relying on leaders. Member participation in organic culture is considered heavily important. This creates commitment to members in completing the tasks and objectives of the organization. Organizations with organic cultures are characterized by tasks that require knowledge and experience, and adjustments through interaction (Neill, Beauvais, \& Scholl 2001).

In previous study, organizational culture in education institutions mapping has been observed in Faculty of Economics and Business, Diponegoro University. The studies were conducted by Kusumaningtyas \& Darmastuti (2016) and create recommendation for institution in preparing the possible challenge toward the transformation of organization vision, mission and values. Culture is regarded as an important element in for organization to anticipate and to adapt to environmental changes for long-term performance success (Kotter \& Heskett 1992). Likewise with the UKTK organization Airlangga University, organizational culture has important elements, functions, and roles in maintaining and developing the organization's vision and mission.

One of the potential major that drives success for organization is a strong organizational culture and appropriate environmental conditions. There are six strong cultural characteristics; the strong core values adopted by the organization, general perceptions or views that are believed and respected by its members; these core values as the main source of valuable strength; good regulation of the core values; core values can be widely accepted and felt together in an organization; and a sense of attachment to existing core values (Chatab 2007). The results obtained from this research are valuable for organization input. Therefore, cultural profiling of an organization is essential ans should be taken into account for organization improvement.

The author seeks to analyze the current organizational culture of Airlangga (University Karawitan Dance Activity Unit or Unit Kegiatan Tari dan Karawitan-UKTK) with the expected organizational culture of members and leaders in the organization. The UKTK organization Airlangga University has set value that appreciates culture, but is the existing organizational culture works expected? Is the organizational culture that the Airlangga University UKTK suitable with its defined vision and mission? By measuring and undertand the suitability of the organizational culture towards, vision and mission will boost organizational performance. The answer of the most dominant type of organizational culture in UKTK Airlangga University wil enable organization to carry out its vision and mission properly. This research is expected to develop behavioral patterns between leaders and members within the organization. This research can also provide a new insight into the existing culture within organizational body as a form of cultural development.

\section{Research Method}

Author designed the research method intended to collect data and carefully observed certain aspects of the research. Conducted in September 2018, this study applies a descriptive method with a quantitative approach. This study has single variable, namely the organizational culture mapping of UKTK of Universitas Airlangga. There are two determinations of sampling techniques used in this research, probability sampling and non-probability sampling. Probability sampling is a sampling technique that provides equal opportunities for members of the population to be sampled, while non probability sampling is a sampling technique that provides different opportunities for members of the population to be taken as a sample (Sugiyono 2013).

The population in this study were all members and administrators of the UKTK Organization of Airlangga University Surabaya. The sampling technique in this study was non-probability sampling (quota sampling) by choosing samples from populations with certain characteristics according to researcher's consideration. The study took 40 respondents as sample. Sample is determined based on the status or position of a person in the UKTK Organization of Airlangga University whether as leader or member of the organization. The sample in this study was used to obtain primary data by distributing questionnaires and interviews to obtain supporting data. 
The instrument of the questionnaire adopted from the OCA tests the validity and reliability of the data. Respondents were asked to provide a rating or likert scale on each question, as shown in Table 1 , with a rating value between 1-4. 1 means strongly agree while 4 means strongly disagree. The OCA questionnaire instrument consists of 20 questions and composed of components of positive statements and negative statements to measure the consistency of respondents' answers. The preparation of questions is based on the five OCA dimensions that can be seen in Table 1. Each OCA dimension has four questions. Table 1 display the form of the question consists of positive questions and negative questions. Each positive and negative question consists of two questions. The sturcure was set to avoid the tendency of respondents to answer only at one end of the rating scale. The model increases the consistency of respondents in answering each question also to avoid irregularities in respondents' patterns of answer. For example, for the dimension of language consists of two positive questions and two negative questions. Each question will be answered by filling in two Likert scale assessments, namely in the preferred culture column on the OCA instrument so that cultural identification can be done not only in the current culture but also to assess the desired culture. After distributing questionnaires and collecting data, data is calculated based on the OCA calculation formula.

Table 1.

OCA research variable of cultural dimension

\begin{tabular}{|c|c|c|c|}
\hline \multirow{2}{*}{ Dimension } & \multicolumn{2}{|c|}{ Question } & \multirow{2}{*}{$\begin{array}{l}\text { Amount of } \\
\text { question }\end{array}$} \\
\hline & Positive & Negative & \\
\hline Language & $\begin{array}{l}\text { - The language used by people in } \\
\text { the organization reflects respect for } \\
\text { other person at all levels in the or- } \\
\text { ganization. } \\
\text { - There is a story about a figure in the } \\
\text { organization who acts as an exam- } \\
\text { ple who perform innovative problem } \\
\text { solving. }\end{array}$ & $\begin{array}{l}\text { - New ideas / ideas rejected with } \\
\text { negative comments, such as } \\
\text { "the idea will not succeed in this } \\
\text { organization". } \\
\text { - Conversations within the organi- } \\
\text { zation show the lack of enthusi- } \\
\text { asm and in activities. }\end{array}$ & 4 \\
\hline $\begin{array}{c}\text { Artifact and } \\
\text { symbol }\end{array}$ & $\begin{array}{l}\text { - There are a number of closed door } \\
\text { in organizations but allow high inter- } \\
\text { action between Members. } \\
\text { - The leader has a workplace but } \\
\text { close relations with other members. }\end{array}$ & $\begin{array}{l}\text { - Leader strictly monitors the time } \\
\text { of arrival and return of mem- } \\
\text { bers. } \\
\text { - Work performance in organiza- } \\
\text { tions is based on punishment/ } \\
\text { avoiding punishment. }\end{array}$ & 4 \\
\hline $\begin{array}{c}\text { Behavioural } \\
\text { pattern }\end{array}$ & $\begin{array}{l}\text { - Members in organizations can ac- } \\
\text { tively develop their knowledge in } \\
\text { order to be able to perform their ac- } \\
\text { tivities better. } \\
\text { - Members care about the problems } \\
\text { faced by the organization and pro- } \\
\text { pose solution. }\end{array}$ & $\begin{array}{l}\text { - Reward is the strongest motiva- } \\
\text { tion that encourage members to } \\
\text { be diligent in their activities. } \\
\text { - Too many trivial things that are } \\
\text { considered as problem in the } \\
\text { organization. }\end{array}$ & 4 \\
\hline Values & $\begin{array}{l}\text { - Collaboration is recognized as a } \\
\text { formal value in the organization. } \\
\text { - Innovation is recognized as a for- } \\
\text { mal value in the organization. }\end{array}$ & $\begin{array}{l}\text { - In performance evaluation there } \\
\text { are many discussion about un- } \\
\text { fair and inaccurate process } \\
\text { - People in organizations tend to } \\
\text { transfer their responsibilities to } \\
\text { others to solve problems. }\end{array}$ & 4 \\
\hline $\begin{array}{c}\text { Basic } \\
\text { assumption }\end{array}$ & $\begin{array}{l}\text { - Leader makes its members feel that } \\
\text { they are important assets for the or- } \\
\text { ganization. } \\
\text { Based on his actions, the leader } \\
\text { considers members responsible, } \\
\text { capable, and reliable. }\end{array}$ & $\begin{array}{l}\text { - Leaders perceive their mem- } \\
\text { bers as an engine. } \\
\text { - Leaders considered themselves } \\
\text { as thinkers while their members } \\
\text { are workers. }\end{array}$ & 4 \\
\hline
\end{tabular}

OCA total score can be calculated based on the individual OCA formula $=\frac{\sum_{1}^{20} Y i j}{n i}$

Notes: $\mathrm{Yij}=$ respond toward question $-\mathrm{j}$ from respondent $-\mathrm{I} \mathrm{ni}=$ total amount of question answered by respondent $-\mathrm{i}$. 
The results of the assessment of each respondent will be summed and mapped based on the type of organizational culture according to OCA method. In OCA, there are two types of culture, mechanistic culture and organic culture. Based on calculations, the type of culture will be obtained according to the score results. There are four classifications of cultural types, a score of 1.0-1.75 including a highly mechanistic organizational culture, a score of 1.76-2.50 including a mechanistic culture, a score of 2.51-3.25 including organic culture, and a score of 3.26-4.0 including a highly organic culture type. The measured cultural types can be analyzed by the suitability and differences between the existing cultures with the expected culture. This measurement is intended to see the suitability between expected culture and cultural realities of an organization.

\section{Result and Disscussion}

\section{Organization vision and mission of UKTK Universitas Airlangga}

The UKTK Organization of Universitas Airlangga is a Surabaya-based student organization that upholds cultural values. During their organizational development process, UKTK of Universitas Airlangga carried out vision, mission, and goals. UKTK of Universitas Airlangga characterized as formal organization because this organization has official organization decree.

The vision of UKTK of Universitas Airlangga in 2018 is to make UKTK as an organization that upholds kinship principles to preserve culture through ideal process in order to and achieve its goals. This vision has been able to provide an overview of organization intention in the long term. To achieve this vision, UKTK of Universitas Airlangga has five missions, namely creating a sense of comfort and sense of belonging, caring for families and families; establish internal and external communication; develop members' interests and talents in dance and music; improve members behavior in terms of diligence and discipline; and maintain the existence of UKTK in external sphere (UKTK 2018). The mission illustrates that $U K T K$ of Universitas Airlangga is engaged in dance and music. The mission was able to create a sense of empathy and sense of belonging between members.

\section{UKTK of Universitas Airlangga respondent characteristic}

After collecting questionnaires that has been filled by the respondents, the results of the questionnaire are processed in the OCA matrix. Respondents in this study were samples from a population of 40 members and administrators of the UKTK Organization of Universitas Airlangga. In this case, the characteristics of the respondents are classified based on age, gender, and the status or position of the respondents in the organization. Table 2 displays the frequency distribution of respondents.

Table 2.

Frequency distribution of respondents based on age, gender, and status in UKTK of Universitas Airlangga

\begin{tabular}{lcccc}
\hline $\begin{array}{c}\text { Respondent } \\
\text { characteristic }\end{array}$ & $\mathbf{n}$ & $\mathbf{( \% )}$ & Current cultural type & Expected culture \\
\hline Age & & & & \\
$\quad<20$ years old & 2 & 5 & 2.30 & 2.28 \\
20-22 years old & 33 & 82.5 & 2.20 & 2.18 \\
$>22$ years old & 5 & 12.5 & 2.12 & 2.24 \\
\hline Sex & 27 & 67.5 & 2.17 & 2.19 \\
$\quad$ Female & 13 & 32.5 & 2.23 & 2.20 \\
$\quad$ Male & & & & \\
Status in organization & & 17.5 & 2.11 & 2.09 \\
$\quad$ Leader & 7 & 2.21 & 2.22 \\
Member & 33 & 82.5 & Source: Primary data
\end{tabular}

Based on characteristics mentioned in Table 2, it is apparent that the respondents in the UKTK of Universitas Airlangga are dominantly aged from 20-22 years old. Analyzed by the age group, the type of current organizational culture felt by respondents with age less than 20 years is a mechanistic 
culture. Observed from the type of culture expected by the respondent group, most of respondent answer that they want a mechanistic culture. Conformity between reality and expectations of organizational culture according to the group of respondents is appropriate, because the difference in value obtained is only equal to 0.02 . The same result about organizational culture values appears in respondents aged 20-22 years. Both groups have the same difference in values between the current cultures with the desired culture in the future. For respondents over the age of 22, they have a mechanistic type of culture. The value gap between reality and cultural expectations desired by the organization has a difference of 0.12 . The number indicates a slightly lower suitability compared to the suitability of respondents of the age group of less than 20 years and 20-22 years. It is interesting to learn that respondents feel and want high efficiency and rely heavily on organization rules.

Organizations with mechanistic culture are more likely to follow the rules. This shows a high level of obidience towards regulations. Based on research conducted by Kanten (2015) mechanistic organizational culture is characterized by the existence of a formal, standarized and centralized function. The definition is close to the type of Culture Hierarchy in the OCAI (Organizational Culture Assessment Instrument) method. There is a similarity between the culture of the Hierarchy and the mechanistic culture because both have characteristics, identified by the existence of rules or policies in the organization.

The amount of female respondent is higher than the male respondent (67.5\%: 32.5\%). In UKTK of Universitas Airlangga, the majority of organizational members were female because of UKTK of Universitas Airlangga takes form of traditional arts which is more popular in female group. Table 2 shows that female and male respondents felt a mechanistic organizational culture in the current culture. Likewise, the desired organizational culture lead to the same result, both group want a mechanistic culture for the future. This shows that between women and men in the UKTK organization Airlangga University expect for high specialization in organization with a clear chain of command. The chain of command is structured with similarities to the hierarchy type of culture. In this type, the dominant characteristics are structured and controlled chain. In addition, the nature of leader acts as a command or coordinator whose orientation is to achieve efficiency (Rangkuti 2016). Clear command in the mechanistic culture at UKTK Airlangga University can support the achievement of their organizational vision. Clear direction from the leaders can develop interests and talents of the members. If the interests and talents of members of the organization grow, UKTK of Airlangga University will gain performance improvement.

\section{Comparison of expected results with the current culture reality from leaders' perspective}

Classified according to respondent's status at the UKTK of Universitas Airlangga, there are seven people whose status is organization leader. There are one main chief of the organization with 6 head of departments. Organizational culture can be created based on the leaders' wishes. Assessment from leaders' point of view is provided more detailed in table 3. The table describes the results of organizational culture that are felt and desired by each individual leader.

Table 3.

Assessment of current cultural reality with expected reality of Leaders of UKTK

\begin{tabular}{cccccccc}
\hline \multicolumn{4}{c}{ Reality of the current culture } & \multicolumn{5}{c}{ Expected culture } \\
\hline No. & $\begin{array}{c}\text { Amount of } \\
\text { response }\end{array}$ & $\begin{array}{c}\text { Amount of } \\
\text { answers }\end{array}$ & $\begin{array}{c}\text { Individual } \\
\text { OCA }\end{array}$ & No. & $\begin{array}{c}\text { Amount of } \\
\text { response }\end{array}$ & $\begin{array}{c}\text { Amount of } \\
\text { answers }\end{array}$ & $\begin{array}{c}\text { Individual } \\
\text { OCA }\end{array}$ \\
\hline 1 & 37 & 20 & 1.85 & 1 & 37 & 20 & 1.85 \\
2 & 44 & 20 & 2.2 & 2 & 45 & 20 & 2.25 \\
3 & 42 & 20 & 2.1 & 3 & 41 & 20 & 2.05 \\
4 & 37 & 20 & 1.85 & 4 & 36 & 20 & 1.8 \\
5 & 40 & 20 & 2 & 5 & 38 & 20 & 1.9 \\
6 & 50 & 20 & 2.5 & 6 & 49 & 20 & 2.45 \\
7 & 46 & 20 & 2.3 & 7 & 47 & 20 & 2.35 \\
\hline Total & $\mathbf{2 9 6}$ & $\mathbf{1 4 0}$ & $\mathbf{2 . 1 1}$ & Total & $\mathbf{2 9 3}$ & $\mathbf{1 4 0}$ & $\mathbf{2 . 0 9}$ \\
\hline \multicolumn{7}{c}{ Source: analysis of primary data }
\end{tabular}


We could learn from Table 3 that the cultural score at the UKTK Organization of Airlangga University is currently felt by the leadership of the organization at 2.11. The score is included in the category of Mechanistic culture. Mechanistic culture has a clear and detailed task structure. Tasks, responsibilities and roles given by the organization's leader are given to the members appropriately. Clear tasks and command could minimize ambiguity and lessen inefficient and inconsistent communication. The results in current cultural reality given by the leaders response prove that leaders is fully responsible for daily tasks in organization such as routine activities, competitions, and meetings.

Type of interaction in mechanistic organizational culture is vertical which includes interaction between superiors and subordinates. These interactions are reciprocal in carrying out organizational functions. Vertical interaction can create collaboration between individual organizations to achieve common goals. This is in accordance with the Mahendra research (2013). Through harmonious interaction between divisions within the organization can increase the motivation and commitment of members to the organization (Mahendra 2013).

An organization with Mechanistic Culture types is identified by its members' behavioral patterns that tend to be governed by leaders' instructions and decisions. Direct control from the leader can reduce the possible risk that organization might face. This is similar to cultural characteristics of the hierarchy, known as member management. The culture provides a sense of security to the members because of control provides by from leader of the organization (Rangkuti 2016). Organizations that embrace the mechanistic type of culture only involves the organization elits for the decision making process. In this case, UKTK Universitas Airlangga made decisions according to the Heads of Department. The authority line in decision making is clear and visible. Similar patterns also occurred in organization with hierarchy culture which also has a clear leadership structure (Cameron \& Quinn 2006).

The results of the scores obtained in table 3 regarding leaders' expected culture of UKTK at 2.09. The scores obtained are included in the category of mechanistic culture types. The data proves that the current culture in the UKTK of Universitas Airlangga has conformity to the leaders' expected culture because the difference in results obtained in the current culture with the leaders' expected culture is 0.02 . An organization will not run or function effectively if the organizational culture is not in accordance with the environment. If the organizational environment is relatively stable, the organization is defined as mechanistic culture (Musfialdy 2012). The compatibility between reality and leaders' expected culture can lead to the effectiveness of organizational activities. This shows that an organization leader wants a clear structure or flow in implementing organization's vision and mission. This intention has similar characteristics with hierarchy culture which focused on efficient, stable and controllable strategy.

\section{Assessment result comparison between leader and members of the current culture and the expected culture}

Based on Table 4, it can be seen that between members and leaders of UKTK of Universitas Airlangga have close score range and show similarities in perceptions about current culture and expected organizational culture, which make it identified as an organization with mechanistic culture. In general, the expected mechanistic culture is characterized by a rigid and controlled structure within the organization. The characteristic of mechanistic culture is similar to the hierarchy of cultural characteristics. According to Rijanto \& Mukaram (2018), a controlled and structured organization has a leader who acts as coordinator, provides security to members, equipped with formal rules and policies, emphasizes stability, and efficiency-based to reach their goals. In a stable and simple environment, mechanistic culture can run more effectively than organic culture. In conducting specialization activities at UKTK, members work clearly and structured with the direction of the organization's power holders. The authority to control and give tasks is belong to organization leaders, thus it creates vertical interactions. In organization with mechanistic culture, leadership does not only depend on beliefs and trust. The process of setting goals is discussed at the top level of the organization and excluding members' participation. Members of the organization tend to follow what is instructed by the leader. Therefore, a centralized process of control occurred in order to suppress or reduce errors. 
Table 4.

OCA assessment result according to member, leaders, and compilation of both of UKTK of Universitas Airlangga

\begin{tabular}{ccc}
\hline Ratings & Type of current culture & Type of expected culture \\
\hline Members & 2.21 & 2.22 \\
Leaders & 2.11 & 2.09 \\
Compilation & 2.19 & 2.19 \\
\hline
\end{tabular}

Based on the results, OCA method is able to show a participatory process to formulate an assessment to produce information about the status of the existing organizational culture. The OCA instrument can provide information about self-assessment tool for organizations. The method can provide information about the expected organizational culture expected by each member. However, OCA method is lacking in comparison method. If we want to compare conditions of different organization, the method is not applicable because the selected indicators will differ from one organization to others. The indicators will be distinguished according to the priority issues of the organization in order to find creative solutions.

Technology and global social change transform the shape of organizational culture. An organization with dominant culture which suitable with the expectations of leaders and members take a high level of commitment and motivation. The reality of organizational culture perceived by members and members' expectations can be a supporting tool for organizations to achieve common goals. Other research states that organizational culture is considered as one of the factors in achieving the goals of an organization (Tanadi 2014). Therefore, organizational culture is very influential to members; behavior patterns. The statement is in supported by research conducted by Fauziah, Pongtuluran, \& Aziz (2016) stating that organizational culture has a positive and significant effect on member performance.

Based on results of organizational culture assessment using the OCA instrument, it is apparent that both leaders and members of the UKTK of Universitas Airlangga agree that they feel mechanistic culture as the current organizational culture. They also want to increase the mechanistic culture in the future. Observed from the organization vision, mechanistic culture is not in accordance with the existing vision because the culture is regarded as a hierarchy in the organizational structure. In contrary, UKTK of Universitas Airlangga vision is to uphold the principle of family. However, the mechanistic culture at UKTK Airlangga University can support the organization's mission to improve the members' behavior. Both of leaders and members of UKTK Airlangga University wish for a mechanistic culture to generate an ideal conditions or relationships within the organization.

\section{Conclusion}

The mapping of organizational culture in the Karawitan Dance Unit (UKTK) of Airlangga University is needed to provide information for organization about the dominant culture they uphold, also to find the most suitable culture for organization environment. The current organizational culture or the expected culture can be measured using OCA method. Organizational culture mapping was conducted by filling out questionnaires given for leaders and members of the UKTK. The results found in this stufy are that the organizational culture that is currently adopted is classified as mechanistic culture. The measurement results of expected organizational culture are also mechanistic culture. The compatibility between the current organizational culture and the expected culture of UKTK can generate a good interaction and harmony within the organization. Both of leaders and members at UKTK have the same cultural expectations and feelings. The existence of similarities between leaders and members encorage organization to reach its goals. The mechanistic culture at UKTK of Universitas Airlangga provides support to the organization's mission such as to improve member discipline. Mechanistic culture considered highly suitable for organizations with high stability such as the UKTK of Universitas Airlangga. The existing mechanistic organizational culture can be a strategy to achieve the objectives of UKTK of Universitas Airlangga. Therefore the results of the study 
can strengthen the organizational culture formed because it can be a powerful means to control and to improve the consistent behavior of members of the organization. In addition, understanding the existing organizational culture can facilitate the implementation of UKTK of Universitas Airlangga programs.

\section{References}

Astuti ADD (2013) Pemetaan Budaya Organisasi Menggunakan Organizational Culture Assessment Instrument (OCAI) pada PT.Perkebunan Nusantara XIII (PERSERO) di Dumai. Universitas Atma Jaya Yogyakarta.

Burns T \& Stalker G (1961) The Management of Innovation. London: Tavistock Publications.

Cameron KS \& Quinn RE (ed) (2006) Diagnosing and Changing Organizational Culture: Based on the Competing Values Framework. San Fransisco: John Wiley \& Sons.

Chatab N (2007) Profil Budaya Organisasi. Bandung: Penerbit Alfabeta.

Fauziah J, Pongtuluran J, \& Aziz M (2016) Pengaruh budaya organisasi, pengembangan karier dan self efficacy terhadap kinerja karya. Jurnal Manajemen 8 (1):43-54.

Iriani RP (2010) Identifikasi dan Analisis Budaya Perusahaan di Pabrik SCC \& C (Spread Cooking Category and Culinary) PT UNILEVER INDONESIA TBK. Skripsi, Institut Pertanian Bogor, Indonesia.

Kanten P, Kanten S, \& Gurlek M (2015) The effects of organizational structures and learning organization on job embeddedness and individual adaptive performance. Procedia Economics and Finance 23:1358-1366. DOI: 10.1016/S2212-5671(15)00523-7.

Knight K \& McDaniel R (1979) Organizations: An Information Systems Perspective. Belmont, CA: Wadsworth Publishing Company.

Kotter JP \& Heskett JL (1992) Corporate Culture and Performance. New York: Free Press.

Kusumaningtyas Y \& Darmastuti I (2016) Analisis pemetaan budaya organisasi menggunakan Organizational Culture Assessment Instrument (OCAI) pada Fakultas Ekonomika dan Bisnis Universitas Diponegoro. Jurnal Studi Manajemen \& Organisasi 13:57-66.

Mahendra S (2013) Hubungan Komunikasi Vertikal dengan Motivasi Kerja Karyawan PT. United Tractor, Tbk. Samarinda. Universitas Mulawarman.

Michelle A (2006) Diagnosing and Changing Organizational Culture: Based on the Competing Values Framework. Personnel Psychology. DOI: 10.1111/j.1744-6570.2006.00052_5.x.

Mills JCH \& Mills A (2000) Handbook of Organizational Culture and Climate. California: Sage.

Musfialdy (2012) Organisasi dan Komunikasi Organisasi. Jurnal Penelitian Sosial Keagamaan 15.

Neill JWO, Beauvais LL, \& Scholl RW (2001) The use of organizational culture and structure to guide strategic behavior: An information processing perspective. Journal of Behavioral and Applied Management 2 (2):132-152.

Sugiyono MP (2013) Metode Penelitian Bisnis (Pendekatan Kuantitatif, Kualitatif dan R\&D).

Rangkuti F (2016) SWOT Balanced Scored: Teknik Menyusun Strategi Korporat yang Efektif plus Cara Mengelola Kinerja dan Resiko.

Reigle RF (2003) Organizational culture assessment: Development of a descriptive test instrument. ProQuest Dissertations and Theses.

Rijanto A \& Mukaram (2018) Pengaruh budaya organisasi terhadap kinerja karyawan (Studi di divisi account executive PT Agrodana Futures). Jurnal Riset Bisnis dan Investasi 4 (2):35-47.

Robbins S \& Judge TA (2008) Perilaku Organisasi. 12th edn. Jakarta: Salemba Empat.

Tanadi M (2014) Pemetaan budaya organisasi di PT. Wisata Dewa Tour dan Travel tahun 2013. EJournal Graduate Unpar 1 (1):45-67.

UKTK (2018) Visi dan Misi UKTK Unair. http://UKTK.ukm.unair.ac.id/2017/02/09/visi-dan-misi/. Winardi J (2003) Teori organisasi dan pengorganisasian. Jakarta: Raja Grafindo Persada.

Zainal VR, Ramly M, Mutis T, \& Arafah W (2014) Manajemen Sumber Daya Manusia untuk Perusahaan: Dari Teori ke Praktik. Jakarta: Rajawali Pers. 